\title{
Stanazolol Measurement
}

National Cancer Institute

\section{Source}

National Cancer Institute. StanazololMeasurement. NCI Thesaurus. Code C75379.

The determination of the amount of stanazolol present in a sample. 